Journal of Development and Communication Studies, Vol. 7. No. 1, January-June, 2020

ISSN (Online \& Print): 2305-7432.

http://www.devcomsjournalmw.org

\title{
Challenges Kenyan Television Journalists Face in Spotting Fake News
}

\author{
Kabucua John Mutugi, Nyakundi Nyamboga, \& Nguri Matu, Moi University, Narobi, \\ Kenya. Corresponding author email: joekabucua@gmail.com
}

\begin{abstract}
A fake news story can travel half way across the world as the truth puts on its socks. There are myriads of challenges facing journalists in spotting fake news hence its wide proliferation. Fake news has become a prominent subject of enquiry especially following its alleged influence of the 2016 general elections in US. Unfortunately, research on fake news has focused on social media, politics, elections, and economies. Few studies have focused on the challenges that TV journalists face in spotting fake news prompting this study. The specific research question was; what are the challenges facing television journalists in spotting fake news in Kenya? The study adapted a relativist-constructivist/interpretivist ontology and epistemology, qualitative approach and multiple case study methodology. Data was generated through in-depth interviews, direct observation and documents review. The study used purposive sampling to generate data from 16 journalists. Data was then analysed in themes and presented in narrative form. Key findings were that in spotting fake news, journalists faced challenges like; loss of viewers, lack of authoritative contacts, sources who gave fake news for personal, business, political, and economic benefits, ability of fake news to camouflage real news, speed of fake news, typologies of fake news, live reporting, inexperienced correspondents and interns, and social media. The study concludes that the challenges facing journalists in spotting fake news were majorly based on sources, technology, education, skills and training, and its typology. The study therefore recommends that editorial boards invest in experts to train journalists on styles, architecture, propagation and use of fake news, inoculation of journalists and audiences, raising fake news literacy levels, and use of technology based approaches like reverse search and fact checking sites.
\end{abstract}

Key words: Fake news, journalists, spotting, challenges, television, Kenya https://doi.org/10.4314/jdcs.v7i1-2.4 


\section{Introduction}

The challenge of fake news has emerged as a new frontier for credibility and trust of journalist and the journalism profession. There has been a declining trust in new and journalism across the world. Today, with the advent of social media in this information age, everybody has become a journalist in the now hyped-citizen journalism. As a result, fake news purveyors have developed sophisticated approaches for propagating their wares. Since journalism is primarily pegged on credibility, speed and trust, fake news has become a thorn thwarting all the three core values. Fake news spread faster through social bots and social media algorithms, is incorrect, and packaged in a way that boarders the truth winning public trust.

At the heart of journalism today is television broadcasting. Although a big percentage of audiences rely on social media for news today, majority of them only believe after confirming from TV. Since TV is audio-visual it easily appeals to audiences. Television journalism has not been left behind by the menace of fake news. In several occasions, TV journalists and media houses have been charged in court, fined, forced to withdraw stories and apologise to their victims of aired fake news. Therefore, most of the TV stations across the globe have put in place structural, psychological and technological measures to spot and counteract fake news. However, the nature of fake news and the shrewdness of its purveyors still remain a challenge to journalist and journalism profession; some fake news still infiltrate to the TV screens.

This paper presents the findings, discussion, conclusion and recommendations of an empirical multi-case study of two news TV station on the challenges faced by TV journalists in Kenya when spotting fake news.

\section{Background}

Fake news has not only been a challenge to journalists in Kenya but across the globe. For instance, in the 2016 general elections in the US, it was alleged that fake news played a major role in installing Donald Trump as the president (Wahutu, 2019, Jameison, 2017). In the second week of November, 2016 the catch phrase "post-truth" was chosen as the US word of the week (Vamanu, 2019, Rochlin, 2017). Former president of U.S Barrack Obama termed fake news on Face book as "dust cloud of nonsense." Reports from Statistica.com indicates that the top 20 fake news on US presidential elections generated more engagements than the top 20 factual stories from trusted media.

During the 2016 US presidential campaigns, fake news stories filled the social media especially Facebook and Twitter (Silverman, 2016). Fake news ranged from Pope Francis endorsing Donald Trump for presidency; Wiki leaks confirmation that Hilary Clinton sold weapons to Islamic States (ISIS); leaked emails by Hillary Clinton to ISIS that their relationship was over; legal confirmation that Hillary Clinton was unfit to hold public office; and that the Federal British Investigation (FBI) agent suspected in Hillary Clinton's email leaks found dead in apartment murder-suicide (Silverman, 2016). This 
fake news came at a crucial time when Americans were going to the poll and the presidential seat was hotly contested by Donald Trump and former Secretary of States for the US, Hillary Clinton. According to research findings by Silverman, during the 2016 U.S general elections fake news were more exchanged on social media than news from mainstream media. In addition, adults in the US believed in fake news headlines $75 \%$ of times they were posted (Silverman \& Singer-Vine, 2016).

In Britain, fake news threatened trust and believability of information hence termed as a threat to democracy (Washington Post, July 27, 2018). This prompted the formation of, the British fake news committee of parliament under the Britain's Digital, Culture, Media and Sport Committee. The committee looked into the issues of Face book data mining, Russian election meddling and Brexit campaign financing. The committee report indicated that fake news was an issue in UK but of importance was how fake news did narrow targeting of citizens using hyper-partisan content skewed towards a certain point of view. The UK parliamentary committee on media attributed Brexit to fake news and questioned the sources of its funding.

In 2016, South Africa faced criticism over human rights violation resulting from a fake news story. The WittyFeed website published an online article indicating that there was a law passed by South African parliament that required all people suffering from Human Immunodeficiency Virus (HIV) be tattooed near their genitals with a mark, "HIVpositive". There was no such law hence this was fake news. However, as a result of this information fear gripped victims of HIV and people rose up in arms against any such legislation especially on online platforms (Workman, 2017).

On October 8, 2014, when Ghana experienced the pick of Ebola outbreak, fake news emerged that Ebola was a lie. This lie 'Ebo-LIE' was purveyed on Face book by Nana Kwame alleged to be a practicing medical doctor. In his post, Kwame said that the Ebola virus did not exist and the said victims of the disease were shot by Red Cross. He further alleged that Ebola crisis was a story made in order to rob natural resources from Africa. This post was immediately aggregated by various blogs and spread on various social media platforms. Patients and health workers quickly reacted to the post, with high number of social media users sharing the post. The fact that it was alleged to have come from a health worker made it look real and believable (Workman, 2017).

In Nigeria, a story emerged on ALJazeer report clip website that Nigeria's President Muhammad Buhari was poisoned but survived. This story was shared on the internet and further circulated by fake news websites. This came at a point when true and untrue stories were making rounds in news concerning President Buhari's health. Since the president was not well and it was common knowledge to the citizens, a good platform for all sort of fake news was watered. This elicited controversy amongst followers and political opponents (Workman, 2017).

Kenya has also been a victim of fake news with misinformation on politics, political leaders, judiciary, and universities leading. For instance, Moi University fell prey 
to fake news purveyors on February 14, 2017 when a fake closure internal memo instructing students to vacate all the campuses by February 15, 2017 and to expect further communication through the university's website went viral on social media (Lubanga, 2017). In a rejoinder, the then Acting Vice-chancellor then, Professor Laban Ayiro dismissed the closure memo as fake (Lubanga, 2017). The fake internal memo bearing university's logo reads:

"This is to inform all the students and staff that with effect from 14th February 2017, all campuses of Moi University shall was indefinitely closed due to the ongoing lecturer's strike," read part of the memo on social media. This comes as a result of senatorial deliberations made on 13th February 2017. All students are therefore expected to vacate the university by 15th February 2017." (Daily Nation, Tuesday February 14, 2017, p.3)

On August 2, 2009 reports on how Dr. Orly Taiz provided evidence showing that president Barrack Obama was not born in United States of America but in Mombasa Kenya went viral on online platforms (Workman, 2017). The evidence was a photograph of a purported certified copy of birth certificate given by the republic of Kenya in 1964 indicating that Barrack Hussein II was born in Mombasa Kenya by Barrack Hussein Obama and Stanley Ann Obama from Durham. The fake news further said that the report was given by an anonymous source who sought anonymity fearing for his life. However, the report turned out to be fake news. Since President Barrack Obama has his roots in Kenya, the story was easily believed especially by the opponents (Workman, 2017).

The 2017 general elections in Kenya also experienced high levels of fake news on social media (MCK, 2018). Various fake news creators and purveyors worked for the major political parties in 2017; Jubilee and National Super Alliance (NASA). Their aim and duty was to manufacture and circulate lies offering an alternative fact to all political issues providing alternative angles to what affected the party or favorable candidate (MCK, 2018).

On Thursday March 15, 2018 news on alleged death of former President Daniel Moi also made rounds on social media after he was taken ill at Tel Aviv hospital in Israel (Mutambo, 2018). Since the former president's health was deteriorating and the information was in public knowledge, purveyors took advantage and were easily believed. Citizens took to social media to engage the report and as a result, the ministry of foreign affairs was forced to clarify that the former president was not dead and was recuperating well in Israel (Mutambo, 2018).

In their June, $201812^{\text {th }}$ issue of The Media Observer magazine, in an article dubbed, "debunking fake news" the Media Council of Kenya (MCK) reported that various institutions in Kenya had fallen victim of fake news. The judiciary of Kenya had also had a fair share of fake news pain (MCK, 2018). Various letters and statements that were purportedly written and signed by chief justice David Maraga issuing certain directives 
had circulated on social media severally (MCK, 2018). It was news if a week lapsed without fake news on death in Kenya (MCK, 2018).

News television stations had also fallen victims of fake news in Kenya. Fake news content creators used fake Tweets of major news television stations' handles names. For instance, on Thursday October 26, 2017 the day Kenya went for repeated presidential election, a fake tweet from a Kenya Television Network (KTN) News handle carried an image of Mohammed Ali a former KTN journalist voting. This was against the instructions from NASA coalition leader that leaders and party members were not to take part in that election. Mohammed Ali was the Member of Parliament for Nyali constituency under Orange Democratic Movement (ODM) hence was not supposed to have voted. However, this was fake news resulted in overwhelming reactions from members of ODM and the constituent that voted for him (Standard Digital News, Saturday October 28, 2017)

Television stations in Kenya have also been charged in court and fined millions of shillings for disseminating fake news. Such happened when Ntv aired fake news on the death of former Member of Parliament and minister in Kenya honorable Njenga Karume. This come when there was increased demand for media accountability globally. Although media stations have various practices and policies to ensure accountability, their implementation was weak and inconsistent (Obuya \& Ong'ondo, 2019).

\section{Problem statement}

Academically, although numerous studies have been conducted in the area of fake news in relation to other aspects like scholarly typologies (TandocJr, Lim, \& Ling, 2018), significance of fake news in influencing social media (Allcott \& Gentzkow, 2017), fake news and post truth economies (Harsin, 2015, Rochlin, 2017), how Donald Trump used fake news during the 2016 presidential campaign and to what extent it contributed to his election victory (Jamieson, 2018), fake news influence on public opinion during elections (Gelfert, 2018, Vanamu, 2019), fake news and information literacy (Neely-Sardon, \& Tignor, 2018), and fake news and its impact on democracy (Wahutu, 2019), few studies have focused on how media especially in Kenya spot and counteract fake news.

Socially, researches indicate a declining trust on media as credible sources of unbiased news information (Wahutu, 2019). According to Dentith (2017) what seems important to modern journalism is not whether the story is true or real but whether people will view it. News facts have therefore become secondary to the gusto for circulation of the news item. The desire for informed publics is quickly being replaced by uninformed mobs (Fairfield, 2018).This comes at the backdrop of increased appetite for online information by the changing mass media audiences. For instance, in the 2016 general elections in the US, the top five fake news on social media (Facebook) got more engagements by audiences than the audiences of the top five news television stations (Silverman, 2016, Jameison, 2019). According to Silverman (2016), the social impact of 
fake news was best highlighted at the height of the 2016 general election in the U.S where the top 20 fake news on election made $8,711,000$ shares, comments and reactions on Facebook compared to 7,367,000 made on the top 20 factual stories most discussed by 19 authentic websites. Therefore, there are calls for an increased demand for validation of information for facts and credibility. Posting of fake news by unauthorized sources targeting certain political change, economic sabotage, or just for pleasure mislead audiences to behave in a certain way (Dentith, 2017).

Contextually, media houses in Kenya have been charged in court, prosecuted and fined for disseminating fake news. For instance, according to Muthoni (2019) the Nation Meida Group (NMG) that owns Ntv was fined eight million shillings for airing fake news about death of city tycoon Jimmy Wanjigi's wife. Although the defense from Nation Media argued that the obituary was placed by a stranger, the judge ruled that the Nation Media benefited financially from the advert and had the responsibility of verifying and airing only factual information (Muthoni, 2019). The Nation television (Ntv) was also charged in court and fined for airing fake breaking news about death of the late minister and Member of Parliament in Kenya Honorable Njenga Karume. This followed a tweet from KTN a competing television station. Since Njenga Karume was only ailing but not dead when Ntv aired fake news of his death, the family sued the television station in court.

\section{Research question (RQ)}

RQ: What are the challenges facing television journalists in spotting fake news in Kenya?

To answer this question, the study adapted the relativist-interpretivist philosophical paradigm hence qualitative approach. The study also applied a multiple case study method consistent with the above worldview and research approach (Jwan \& Ong'ondo, 2011). Having two case studies widened my perspective (Rubin \& Rubin, 2005) on challenges that faced TV journalists in combating fake news in Kenya. Data was generated through in-depth interviews, documents reviews and observations. Generated data was then analysed thematically and later presented in narrative form (Details under methodology).

\section{Literature review}

Fake news is not a new phenomenon but has recently attracted attention of researchers and media practitioners following its alleged role in the 2016 general election in United States of America (Silerma, 2017, Wahutu, 2019). The term post truth was chosen as the Collins dictionary word of the year in 2017 (Daniels, 2017). According to CNBC, 70\% of the people in the world are worried about fake news (CNBC Monday 22 February, 2018). Daniels (2017) further asserts that the average person has no knowledge to distinguish 
credible news from fake news. Social media algorithms and online bots in the information age have exacerbated the challenge of fake news (Jameison, 2017).

The term fake news has been conceptualised variedly by different scholars. According to Gelfert (2018), fake news is the deliberate presentation of false and misleading claims as news with a deliberate design to mislead. While some see fake news as propaganda, hoax, trolls and satire (Verstraete, Bambauer \& Bambauer, 2017), others see fake news as news stories that have no factual basis but are presented as fact (Alcott \& Gentzkow, 2017). In addition, Housh defines fake news as "content that is deliberately false and published on websites that mimic traditional news websites" (Housh, 2018, p.1)". Common in typologies of fake news is the deliberate nature of fake news to mislead. Fake news can be motivated by factors like politics, fun, business rivalry, of just to mislead and cause panic (Silverman, 2017). Whether fake news is in the form of propaganda, trolls, hoax, satire, pseudoscience or error, the underlying factor is its deliberate goal to mislead. Variation in conceptualisation of fake news by scholars and journalism practitioners is at the heart of challenges in spotting fake news (Gelfert, 2018).

In this paper, spotting refers to the processes put in place to appraise information and identify fake news. Various spotting practices can be used to stem fake news. To begin with, news television stations can engage the services of digital researchers and make them in-house news staff (Gelfert, 2018). These experts are instrumental in the process of digital mapping and tracing fake news algorithms on social media. Research enhances fact-checking which increases the chances of spotting fake news (TandocJr, Lim, \& Ling, 2018).

Secondly, media experts can also do listing of data experts to consult incase of news information whose truthfulness or falseness they are not completely sure of (Wahutu, 2019). Various data experts and fact checkers like Snopes, PolitiFacts and Factcheck.org have been vital resources to journalist (Himma-Kadakas, 2017). A close working relationship between media experts and data experts enhances verification of news before dissemination (Goldman, 2001). This is especially important in the modern day journalism where social media seems to be setting the agenda for the mainstream media. However, according to Brooke (2017), fact checkers and data experts are not a panacea for managing fake news. Confirmation of dubious information with fact checkers is a primary prerequisite for editing in journalism (Bermúdez, 2018).

Thirdly, news television stations can develop pointers to sources for instance the use of reverse search technology. These are important verification agents that enable journalists to trace back the source of information and verify its originality (Berinsky, 2017).

Verstraete, Bambauer and Bambauer (2017), aver that communicators can identify fake news by looking at whether the author intended to misinform, and whether the motive of the misinformation was financial. Through this, one can be able to categorize fake news as propaganda, hoax, satire or trolling. 


\section{Gate keeping theory}

The Gate keeping theory helped in conceptualizing what happens to fake news when it gets to reporters and editors in the field or in TV newsrooms. Gate keeping theory also brought to the fore the critical roles played by journalists, management and regulators in determining news from non-news.

The phrase "Gate keeping" was coined by Kurt Lewin to refer to the process of blocking and or discarding information that is useless or unwanted using a gate or filter (Shoemaker \& Vos, 2009). Lewin referred to the person who makes decisions on what to allow in and what to discard as the gatekeeper. Therefore the concept of gate keeping involves gatekeepers (individuals or groups) who make decision on what information to allow to certain individuals or groups and what not to. The gatekeepers act as decision makers for the larger group that depend on them for information. Gatekeepers are influenced by personal, regulatory, cultural or social factors in filtering what gets into the system and what is left. Through such gates, the gate keeper is able to regulate information flow by barring sensational, controversial or unwanted information from reaching the audience or entering a system (Shoemaker \&Vos, 2009).

This theory fitted well in conceptualizing the study of spotting and counteracting fake news. The Gate keeping theory posit that in news media, editors decide on what news item to publish and what to discard based on the house policies, ethics, and book (Shoemaker \&Vos, 2009). The editors and the reporters on the ground receive volumes of news items but have to decide on what to let to the public and what not to. This implies that well informed and trained journalists will easily spot and discard fake news. In the same vein, the Gate keeping theory helped me conceptualize the way fake news purveyors' filter certain news and decide on items that make circles on social media. Shoemaker and Vos (2009) further affirm that in deciding what to allow and what to discard, gate keepers are influenced by social, political, cultural and regulatory factors. Gate keeping theory posits that, editors remove controversial and unwanted information from news in order to control the society to certain directions. It is in the process of cross checking that fake news can be spotted. However, gate keeping theory informs of factors that may influence the gate keepers like political, social, religious and economic (Shoemaker \&Vos, 2009). Fake news may therefore filter into the TV screens if reporters and editors are not independent actors.

\section{Methodology}

This study adopted a relativist-interpretive/constructivist ontology and epistemology philosophical paradigms (Rubin \& Rubin, 2005). According to Rubin and Rubin (2005), a research paradigm provides a way of looking at the world and interpreting what is studied. It indicates how research was carried out, by whom, the degree of involvement and interpretation hence the use of pronoun ' $I$ ' in this study. In line with this worldview 
the study followed a qualitative approach and a multiple case study methodology as advised by Creswell (2007). Purposive sampling was adapted in sampling 16 participants for the study. The target population comprised of editors and reporters and the study location was in the newsrooms of the two case studies; Nation TV and KBC TV at their headquarters in Nairobi County in Kenya. Data was generated through in-depth interviews, direct observation and documents review. Data was then analysed thematically and presented in narrative form. Trustworthiness of the study was assured through credibility, generalisability, and transferability measures as advised by Jwan and Ong' ondo (2011). Ethical measures like anonymity and privacy were also ascertained.

\section{Findings}

Editors and reporters in Kenyan television stations face a myriad of challenges in spotting fake news. These challenges included; loss of viewers to competitor TV stations, lack of authoritative contacts to confirm authenticity of news, sources who gave fake news for personal, business, and economic benefits, ability of fake news to camouflage real news, speed of fake news, unclear definition of fake news, live reporting, uncooperative sources, inexperienced correspondents and interns, and social media. Findings on these challenges are presented below.

\section{Competition for and Loss of Viewers to Rival TV Stations}

Speed is of essence in journalism especially in news gathering, processing and dissemination. Participants were of the view that the rigorous process of verifying and crosschecking every spoke of news had resulted to loss of viewers who deliberately migrate to other TV stations. A viewer will get a heads up about certain breaking news through social media and immediately switch on to their favorite TV to confirm. If the station has not yet aired the breaking news, they will quickly zap to another station and if the same happens they will move to another and another until they find a station airing what they were looking for. As participant A1 narrated;

The challenges are, as you delay, in broadcasting, in going on air you lose viewers. When something happens, people now, because we are dealing with TV here, when they are told this and this has happened they go quickly to TVs and use a remote and check who is live from the location? So if you are not, people write you off and move to another channel? (A1).

This was corroborated by findings from KBC editorial policy document and observation. The policy asserted that facts and accuracy were more important than speed. Therefore, KBC TV journalists were not supposed to worry about loss of viewers to rival stations based on delays in breaking news. The document indicated; 
We must take cognizance of the fact that accuracy is more important than speed and it is often more than a question of getting facts right (KBC editorial policy, 2008, p.2).

Observation of movements from station A was also relaxed and composed. Journalists in this station took slower and moderate moves from one point to the other in the newsroom. I also observed several journalist share and chart in relaxed moods in station A (AMOB).

Participants also informed that if this was repeatedly done and viewers found that your television channel is always late with breaking news, they permanently migrate to channels that were fast enough to give them the confirmation they wanted in time. The same thing happened whenever there was breaking news and their television favorite channel was not live on location; viewers quickly moved to the channel broadcasting live on location. Viewers want to confirm, and affirm the news they have already received from social media. The social media sets the pace for the mainstream media and this affect the migration of viewers from one television channel to another. Television is used for reinforcing what viewers have already heard or watched from unconventional media. When journalist from TV delay in serving this need as they countercheck and cross examine news for fake news, they lose their viewers to televisions stations that would dare move with shallow confirmation. This is what participants called, "scooping the news".

So one of the challenges is losing viewers on TV because you, you are trying to go the safe way and now the person who gets its first, draws the viewers (A1).

Maybe sometimes you want to scoop a story and you want to write it so that you can get it faster than the rest so that's a challenge. You are between can I wait or can I go on. That's the main challenge. If you wait a little bit longer, the other station reports it. They scoop the story, it goes with them. Sometimes when you call for clarification they take a little bit time before they get back (A8).

Participants informed that some television stations had been sued of disseminating fake news out of their rush to scoop stories on television as breaking news ahead of their competitor. A competing television station had tweeted about the death of a senior politician and the other station saw the tweet. The station's editors made shallow consultations in the newsroom and a decision was reach that they go on air with the breaking news that the politician was dead. However, the tweeting television station had not gone on air with the news. Immediately the receiving station broke the news, the spouse to the politician said to be dead called and disputed it. The station was therefore sued for defamation and several editors lost their jobs.

The only incident I can remember is about fake news that involved Ntv and we were even sued about Njenga Karume. There was a time KTN tweeted, several years ago before he died that he is dead. The editor on duty saw that tweet on KTN 
and made a few consultations in-house. Should we wait to contact the family to verify? Or we shouldn't wait? A decision was made. If KTN has tweeted it then it must be true. So we proceeded with it. The family sees it, and immediately calls that he is not dead and we were sued. We were sued for hundreds of millions of shillings with damages. We only got away with it because later on barely two weeks later, the man actually died. He passed on, but that editor who was on duty that day was fired. He was fired because you see, for a company like Nation Media being who we are, we cannot get away with such things. You see KTN tweeted it and they were not sued. They were the first ones to tweet it but they were not sued. We were the ones who were sued, because we are Nation Media. So fake news can actually originate from another media house yes, and get you in trouble (B11).

This can be affirmed by the observations made in both KBC TV and NTV newsrooms. In all the days of conducting this research in newsrooms, there were large screens on the walls with other TV channels running.

I observed that in NTV newsroom there were several TV screens mounted on walls and pillars. These TV screens were tuned to other local channels like Citizen TV, KTN, KTN News, K24, and KBC TV. Reporters and editors in the open hall of the newsroom were monitoring them while still working (BMWOB).

In the newsroom of television stations were large screens with competitor's channels running. In fact, I observed that in one news room there were more than four competitor channels running and strategically positioned to be watched by various journalists as they continued with their duties. Those channels run throughout the day and were meant to monitors the competitors. On the contrary, in KBC TV newsroom, there were a few TV screens that were all tuned to KBC TV channel. This was a confirmation of the previous findings from documents reviews and interview with A1 that KBC TV was never after speed of broadcasting but accuracy and facts.

In KBC television newsroom, I found a few TV screens mounted on the walls and that were all tuned to KBC TV channel (AMWOB).

Competition amongst television stations in Kenya was real and sometimes it had resulted to underground rivalry. Some participants even thought that in the above cited case, KTN would not have been sued of fake news about Njenga Karume despite being the first to tweet about fake news of death, but their competitor NTV was sued. This was a reflection of television rivalry in Kenya resulting from competition for viewers. Participants were for the view that television news was commercial and they had to monitor each other for scoops. The fight for viewers was therefore real and stations monitored each other so that in case one station scooped a story before another, the outwitted one would quickly send reporters to the ground to source for the story. This was a real challenge to the top television stations in Kenya. 
That is KTN that is on but sometimes we will put on Citizen there. I am very sure that the screen that faces you is citizen. We look at competition also. This is a competitive business. We look at Citizen, we look at KTN. Those are our true competitors in the mainstream media. KBC and K24 are important. So yes we will dedicate time. We actually are in the process of making this one a face for all of them. But we monitor each other. If I walk in for instance to Citizen, I expect I will find a screen on us, then on KTN, then K24 and the rest (B10).

This observation by participant B10 indicated that he was very sure that on his front side was KTN channel running while behind him was a TV screen that run Citizen TV throughout the day. His kinesics portrayed the confidence he had with obtaining continuous news from the competing local TV stations (B10 OB).

\section{Challenges with the Source}

Source related challenges to spotting fake news included; lack of authoritative sources, sources that give fake news for personal gain, and uncooperative sources.

\section{Lack of Authoritative Contacts to Confirm Authenticity of News}

In some instances editors and reporter got access to unsubstantiated crucial news information but lacked credible sources to confirm it. Other sources preferred remaining anonymous contrary to most of the editorial policy documents. Since there was wide spread fake news in the current airwaves, journalists were made to wait or discard that news since they lacked authoritative contacts to prove authenticity of stories. The worst happened when rival television stations had better contact list and were able to confirm the story earlier and go on air hence scooping it. Editorial policy of KBCTV read;

We should try to minimize the use of anonymous sources unless we are sure that the information obtained is irreproachable (KBC editorial policy, 2008, p.6).

In other instances, the source that gave the story to the reporters on the ground became uncooperative and unwilling to confirm the details of their information. Sources feared being seen on television screens and others having their names broadcasted. Other sources deliberately refused to engage about an issue they had earlier talked about. Uncooperative sources made the process of spotting fake news difficult. In some instances journalist were forced to drop a good story. In other instances, journalist would hide under the veil of "unconfirmed reports" and go on air with the story just to ensure they had the scoop. This enabled them buy time to look for authentic sources to confirm the story.

But you lose a lot when you cannot get someone to confirm the authenticity of that information (A1).

In sensitive cases if it is very sensitive and it must go, we opt for a safer option by saying unconfirmed report. You will get away with it because nobody will hold 
you responsible. How did you get this information? How did you know? you get away with it by saying unconfirmed report indicate that. You see that is safe, it is really safe (A4).

However, findings from document review from both station A and B differed with the above interview findings. The editorial policies were firm on verification and avoidance of anonymous sources. News was to be verified and sources disclosed on air. The documents read:

The Group's news and information outlets must remain independent of vested interests or external influences. Its news and information outlets are committed to being comprehensive and accurate in content and their commentaries fair and considered. Their constant objective is to ascertain and verify the truth of what they publish insofar as this can be established (Nation media Group Editorial Policy, para 4, p.2).

...we should normally identify on air and on camera sources of our information (KBC editorial policy, 2008, p.6).

The issue of contact in Kenyan television space was very important. In fact, one participant compared a journalist without contacts to a farmer without a jembe; just like a farmer cannot farm without a jembe, so can't a journalist process news without contacts. To them there was nothing much a journalist could do without contacts. In fact, participants felt that the need for contacts in journalism had been raised up and some had to bribe to get contacts with senior officials; they bought drinks and took them out to create good rapport. Having good contacts with senior persons in the governments and other organizations meant quick access to information whenever the need arose. Actually, some stories were only assigned to reporters with good rapport and contacts. This may raise questions of standards and accountability in news processing, but that was the case with television stations in Kenya.

The contact is key, even in governments now, when things happen, the person who becomes the first one is the one with contacts. That is why, where I sit, mainly is to help the reporters with contacts because of your experience and your connections (A1).

\section{Sources Who Give Fake News for Personal, Business, and Economic Benefits}

Television journalists also received news from sources with ulterior motives. Some sources gave information for their own benefits. This happed mostly during political competitions where rival candidates and their supporters gave slanted information to settle political scores. Others gave fake news for economic benefits. Such cases would also happen where competing companies gave fake news about their competitors to sway perceptions of customers. The major goals of such economic fake news was to disrupt economic trends; make rival companies be seen in a negative light hence lose clients. Fake news about death of politicians was also common. Purveyors of such fake news like the 
death of Kibera Member of Parliament Hon. Ken Okoth, former President Moi and Njenga Karume did so to move political opinions and settle political scores.

Some people give you fake information for their own benefits. Case in point is during political competition. Someone who literally, someone you know can give you fake information for their political benefit, others for their business benefits.

People can give you fake news to benefit their business, their companies or to benefit themselves politically and people who have perfected this are politicians (A1).

Some of the correspondents that television stations employed and trusted as new gatherers in certain locations also become a challenge when they develop the urge to make quick and more cash. Unscrupulous correspondent therefore picked materials from the internet or manipulated information and sent it as real and current news to television stations. This became difficult for the editors in the news rooms to suspect as fake news since they were internal employees. Such fake news passed through the editorial process and resulted in embarrassments and court suits for the television stations.

The biggest challenge that we have faced is the people who are thinking of making some quick money. There is actually somebody who actually brought us a video here saying these are people of South Sudan who are being beaten up by police and we could see guys are being hacked with machetes and they are trying to run away (B9).

Stage managed fake news was a new form of fake news. There were also deliberate efforts to penetrate the mainstream television stations with fake news owing to their ability to amplify disinformation. Participants decried increasing rate of stage managed fake news that was aimed at duping television stations into fake news. Spotting of fake news in such stories was a major challenge to reporters and editors. The purveyors of stage managed fake news set up elaborate schemes to send written news to the newsrooms with clear contacts that actually worked. Editors would then call the contacts in the documents and conform from or visit the websites that the purveyors had set up and believed to be real news. Such set up had happened in television stations in Kenya and had passed through the gate keepers without being detected. This was common in Kenya since fake news purveyors had learnt that editors verified news through phone calls.

Such a case happened about a fake news story of a political candidate during the 2017 general election in Kenya. A well orchestrated fake news story about how Steve Mbogo's helicopter used to make a lot of noise while landing in the evening and leaving in the morning and how the noise disturbed residents of Karen estate in Nairobi was sent to the editors. The formal complain had contacts of the purported officials of Karen residents association. The editors called the numbers and the receiver confirmed that, that was the situation in their residential area. The editors then resolved to go on air with the story. It was only after the story was aired on Ntv that the actual residents of Karen called 
and editors realized that they had been duped to fake news. In fact, participants felt sorry for falling to this kind of fake news.

One day we get a press release online of an association calling itself Karen Residents Association writing a letter as a press release to media houses saying they need help because Steve Mbogo's chopper makes a lot of noise leaving in the morning and lading in the evening so it makes a lot of noise. And the press release has even a number of someone pretending to be an official of Karen Residents Association. So when you get the press release, he doesn't even own a chopper then you looks at it and verify I said the first thing they even had a number of someone. Then I go online and find there is Karen Residents Association so I call the number and they say yes this is Monica from Karen residents Association how may I assist you? Is this letter from you? Yes, it is from us. What is the complaint? Oh there is this guy who does this and that. Okay, so it is from you. So immediately, you have no doubts to rise because there is an official who is listed and who you have spoken to so you run. Then, the story is on air and the real Karen Residents Association are watching and are wondering what this is. Then they call the station and say there are no such complaints from us. Then you realize that it is fake news (B13).

\begin{abstract}
Ability of Fake News to Camouflage Real News
Another challenge that faced television editors and journalist in spotting fake news was its ability to camouflage real news. Fake news purveyors package it to look like real news and that is why media stations fall for it. Appearance of fake news therefore makes unsuspecting persons believe that it is real and factual. The more a fake news story is spread, the more people accessing it believe that it is real. Purveyors of fake news exploit this fact and work on algorithms that makes it spread faster though shares and amplification on mainstream media like television. Fake news look like real news and may have spokes of truth. This makes it difficult for the editors and reporters to spot. Fake news purveyors also develop websites, blogs, social media platforms, and domain names that mimic those of authentic organizations and governments. Participants opined that fake news purveyors come up with a spreadsheet that camouflages that of New York Times and use it to share news. Unsuspecting journalist will then pick it and air it and even attribute it to New York Times only to be denounced by the actual organization. This makes it difficult for editors and reporters to detect. The complicated nature and appearance of fake news sources had therefore made television stations fall for it.

The main challenge is like if someone wants to push an agenda that is not factual. Because sometimes they can present it in such a way that will be very hard pressed to question and looks like it's very true (B12).
\end{abstract}




\section{Speed of Fake News}

Participants also felt that the speed of fake news was a challenge. Since individuals look for information that reinforces their already held believes, any news that they receive whether fake or real news, they easily believe and share. Fake news sharing patters are also very fast making it travels really fast. Before, a reporter or journalist calls various sources to countercheck news spotted on social media platforms, the news has already made rounds across the globe. Some participants opted to go on air with unconfirmed stories labeled as "unconfirmed reports" just to ensure that they did not lag behind in the scoops. This practice was used to enable TV stations buy time to confirm news from various sources.

One challenge is always the urge to be faster, speed. The urge for speed in newsroom is that once in while you may sleep up and get your gun down because at times you feel that it will take long to call and with the digital platform if you go online you get news very fast. That is the key challenge of trying to be the first one (B16).

On observation of movements of journalists in station B, I realized that they moved fast, looked tensed and glued to their editing screens to hit set deadlines (BMVOB).

In sensitive cases if it is very sensitive and it must go we opt for a safer option by saying unconfirmed report. You will get away with it because nobody will hold you responsible that how did you get this information, how did you know you get away with it by saying unconfirmed report indicate that. You see that is safe, it is really safe (A4).

\section{Unclear Definition of Fake News}

There was also a challenge in the way journalists differed in conceptualizing the term fake news. What one journalist would call fake news was different from the other and so did it differ from one television station to another. Other participants though that their media houses needed to redefine fake news clearly for them. It was therefore clear that there existed varied conceptualization of fake new which affected the spotting practices. What one journalist would spot as fake news would therefore pass through another ones hands as real news. Some participants believed that fake news depended on the person claiming it was fake news; it could be the mainstream media, the politicians, policy makers, analysts or commentators. The media would therefore pick it as fake news depending on the party. Participants also opined that journalists defined fake news differently, and the perception of fake news held by one differed from the other.

You see for us, fake news depends on who is claiming it is fake news. Are we, the mainstream media claiming that its fake news? Is the politician claiming it is fake news? Is the average viewer claiming that it is fake news? Are policy makers claiming it is fake news? Are analysts and commentators claiming that it is fake 
news? So for a media house it depends on whose perspective this piece of information is being described as fake. (B13).

I think we may need to go back and define fake news from where we sit (B12).

\section{Live Reporting}

Live reporting common in modern TV broadcasting was also a challenge in spotting fake news. News broadcasted live from location did not go through the normal process of gate keeping. There were no interruptions and what the source said from location was streamed live and directly to audiences. In such cases, if a reporter on the ground did not spot certain fake news while reporting, the same was relayed to the audiences. However, some television stations had adapted a delay tactic where live reporting was delayed for some seconds especially in political rallies where chances of fake news were high.

Journalists did not have enough time to confirm facts when reporting from on the scene where an incident had happened. For instance, when a reporter was on a scene of terror attack, they were not able to go inside the building where terrorist were and confirm how many people were killed. In such cases, if journalist gave an exact figure, the figure could not be factual and the station could be accused of disseminating fake news. Participants also opined that, when doing live reporting, a reporter did not have time to verify sources they pick to give opinions. A source picked for opinion in a scene of accident or terror attack could therefore deliberately air fake statement that result in the station being accused of disseminating fake news. What fake news purveyors look for in mainstream media are avenues for amplification, live reporting served that. The reporters and editors in the newsroom had no opportunity to go to the ground and verify the information given by sources in live reporting.

One of the dangerous aspects of television is what we are now calling live reporting. I have invested in about ten modern broadcasting facilities that are core TV use. And when news breaks you move there and you start reporting live. It is live. Where are you? We are at DUSIT terrorists have attacked DUSIT. So you start transmitting. One of the biggest dangers I am finding is that live reporting. Someone comes and says, two hundred people died here and they are inside there, you know it's already on air no control the reporter has picked an eye witness and they are going live. (A1).

\section{Social Media}

Social media was the major platforms on which fake news thrived. Conventional television stations had fallen victims of fake news on social media. Participants lamented of how their television station was duped to fake news from a twitter handle of another television station. During the incident, Kenya Television Network (KTN) tweeted about the death of a former Member of Parliament and Minister in Kenya through their official 
twitter handle. Since television stations monitor each other from the newsrooms, NTV journalist saw the tweet and the editor on duty at the time consulted several journalists in the newsroom and a decision was reach to air it. The basis of airing fake news about death of Njenga Karume was arrived at based on the fact that KTN was a major station and rarely would they tweet fake content. However, immediately NTV went on air with the breaking news on their channel, the family of Njenga Karume called and said he was not dead. This was actually followed by a legal suit of the television station and its editor. This indicated how fake news had penetrated social media and how it exploited amplification ability of conventional media like television.

...due to random or the viral nature of fake news on social media makes it hard for you know to follow up what is happening to get the facts because you know in social media it goes so fast, in a network platform where more than ten million Kenyans are in that viral element on how it's spread on WhatsApp, Twitter and Facebook. I think it has been challenging not only for KBC but the whole media fraternity (A2).

The actually only incident that I can remember about fake news involving Ntv and we were even sued was about Njenga Karume. There was a time KTN tweeted several years ago before he died. The editor on duty saw that tweet on KTN and made a few consultations in-house, should we wait to contact the family to verify? Or we shouldn't wait? A decision was made. If KTN has tweeted it then definitely it must be true. So we proceeded with it. So this editor also tweets. The family sees it, and immediately calls that he is not dead and we were sued. We were sued for hundreds of millions of shillings with damages (B11).

\section{Discussion}

This study sought to answer the question of the challenges facing TV journalists in spotting fake news through a multiple case study of two news TV stations in Kenya. The following is a discussion of the findings from in depth interviews, observations and documents review in the lens of the gate keeping theory and reviewed literature.

\section{Competition for and Loss of Viewers to Rival TV Stations}

It was clear from the findings that TV audiences did not have to get facts in order to believe news stories; what trended and was widely shared was easily believed as Bermudez had noted, "belief no longer has to follow fact" (Bermúdez, 2018, p. 88). This made TV stations that were keen on counterchecking fake news lose viewers to stations that shallowly did.

Findings that TV viewers zapped from one channel to the other looking for one airing breaking news affirms previous assertion on how public reason beyond facts when seeking information to satisfy their thirst for news (Dentith, 2017). The challenge of fake 
news verification under the pressure of competition amongst rival stations had led to court charges, fines and mandatory apologies by TV stations. This seconded the findings from Muthoni (2019) that the Nation Meida Group (NMG) that owns Ntv was fined eight million shillings for airing fake news about death of city tycoon Jimmy Wanjigi's wife. Although the defense from Nation Media argued that the obituary was placed by a stranger, the judge ruled that Nation Media benefited financially from the advert and had the responsibility of verifying and airing only factual information (Muthoni, 2019).

\section{Challenges with the Source}

\section{Lack of Authoritative Contacts to Confirm Authenticity of News}

Findings that participants lacked authoritative sources to affirm news indicates another challenge faced by journalists. Most of the sources that front themselves to give news information about an incidence have ulterior motives and a past reputation for disinformation. According to Fallis (2004), affirming the reputation of a source within tight deadlines is a major challenge to TV journalists. In spotting fake news, journalists must overcome the challenge of sources' feelings triumphing over reason hence know what is said out of emotions and reason (Fairfield, 2018).

\section{Sources Who Give Fake News for Personal, Business, and Economic Benefits}

It was also clear that participants faced the challenge of sources that gave information in order to achieve personal, business, political or economic ends. It is therefore important that editors research about the sources and trace incidences of such acts by the source. As Goldman advises, editors should seek to know source's "past track record" to avoid such traps (Goldman, 2001, p. 106).

As with the findings of this study use of fake news for economic, social and political purposes previous scholars realized that fake news had a fair influence on elections for instance in the 2016 general elections in the US (Wahutu, 2019, Silverman, 2017, Jameison, 2018). In addition, nations have used fake news to manipulate and influence economic and political environments across borders. For instance, fake news war waged by Russian agencies against certain Russophobe political organizations competing in elections in Ukraine and the United States (Khaldarova, 2016).

\section{Ability of Fake News to Camouflage Real News}

Findings from documents review and interviews indicated that spotting fake news was made more difficult by its close resemblance with real news. Fake news has the ability to camouflage real news making it difficult for editors to detect (Harsin, 2015). As participants lamented that there is no fake news that comes labeled, so did the review of the editorial policy document from KBC and Ntv television stations indicate as 
challenges that internet sourced news posed to the process of spotting fake news. Fake news appear in varied forms and types (Rochlin, 2017).

As Steinberg (2017) affirms, fake news may refer to any of the ten types: propaganda, click bait, sponsored content, satire and hoax, error, partisan, conspiracy theory, pseudoscience, misinformation, and bogus. From the literature reviewed, fake news on former president of Kenya, the late Daniel Moi's death was purveyed while he was hospitalized in Tel Aviv (Mutambo, 2018). Fake news is usually well orchestrated and timely making it appeal to preconceived thoughts and ideas in the minds of the target audiences (Cooke, 2007). This poses a challenge to editors waging war against fake news. From the gate keeping theory that conceptualized this study, editors' spot fake news at the filter gates through which all news from the field pass through. As Shoemaker and Vos assert, through such gates, the gate keeper is able to regulate information flow by barring sensational, controversial or unwanted information from reaching the audience or entering a system (Shoemaker \& Vos, 2009). However, as the participants opined, when fake news camouflages real news, it becomes a green snake in green grass therefore spotting it is made more difficult.

\section{Speed of Fake News}

From the participants, the speed at which fake news move from one person to the other poses a threat to the process of spotting it. Fake news purveyors ensure that there is a possibility of being reposted, commented on, and or shared to enhance clicks and conversations around it (Garcia \& Lear, 2016). This was also witness in the fake news on 2016 general elections in the US for instance; fake news about Clinton's weapons of mass destruction and Pope's endorsement of Donald Trump received more shares and views that real news (Silverman, 2016, Jameison, 2018). The speed of fake news is also validated by bots and echo chambers that speedily amplify it making it reach a huge audience (Lokot \& Diakopoulos, 2016).

Since TV journalist work under tight deadlines and close monitoring they have inadequate time to filter, research and find facts on news as posed by the gate keeping theory (Shoemaker \& Vos, 2009). For instance, as the findings indicated, it was out of speed to make scoops on the death of former cabinet minister in Kenya, Hon. Njenga Karume that Ntv aired a fake news story on his death.

\section{Unclear Definition of Fake News}

From the findings, the other challenge that faced participants in spotting fake news was its typologies. It is difficult to detect the unknown. Various scholars define fake news differently, for instance, as "the deliberate presentation of false or misleading claims, where the claims are misleading by design" (Gelfert, 2018, p. 108), as propaganda, click bait, sponsored content, satire and hoax, error, partisan, conspiracy theory, 
pseudoscience, misinformation, and bogus (Steinberg, 2017), as post truth (Harsin, 2015), or deliberate misinformation (Gelfert, 2018). This variation in definition makes it difficult for journalist to develop a standard procedure of detection. Knowledge on what fake news is and what it is not is therefore an important skill for journalist in fake news detection (Neely-Sardon \& Tignor, 2018, Pogue, 2017, Bluemle, 2018).

Other scholars have opined that fake news has a variety of typologies hence knowledge of one or two types cannot guarantee complete identification (TandocJr, Lim, \& Ling, 2018). Since media practitioners have a social responsibility to the audience, their media houses, profession and employers, accountability in information verification is basic (Obuya \& Ong'ondo, 2019). This is a handle that journalist have to overcome in the war on fake news.

\section{Social Media}

Findings from in depth interviews, observation and documents review also indicated that social media was a double edged sword in spotting of fake news. Participants used social media technology in spotting fake news for instance formation of newsroom social media groups for collective verification. Through social media technology editors are also able to spot fake news faster and in a wide range of forms (Soe, 2018). However, social media also made it difficult for journalist to spot fake news for instance, it was the avenue through which fake news escaped the editors (Bluemle, 2018), it amplified fake news through bots, echo chambers and through it audiences' shared unverified news (Steinberg, 2017). For instance, this affirms assertion by Allcott and Gentzkow (2017) that, 115 pro-Trump fake stories were shared on Facebook 30 million times, and 41 pro-Clinton fake stories were shared 7.6 million times (Silverman, 2016).

Literature reviewed also indicated that fake news about closure of Moi University in Kenya on a fake memo from the acting vice chancellor then, professor Laban Ayiro was shared fast though social media algorithms causing tension amongst students (Lubaga, 2017). Although counteraction of fake news hardly changes beliefs in peoples' minds, the same way audiences share fake news, they also share corrections (Cook, 2017). However, social media remains a challenge to TV journalists' efforts in spotting fake news in Kenya.

\section{Conclusion}

In conclusion, this study sought to answer the question of challenges facing TV stations in spotting fake news though a multi-case study of two news television stations in Kenya. The study adapted a qualitative approach and generated data through in depth interviews, observations and document reviews. Data was analyzed through themes and presented in narrative form. Major findings indicated that TV journalists faced the following challenges in spotting fake news; loss of viewers to competitor TV stations, lack of authoritative contacts to confirm authenticity of news, sources who give fake news for 
personal, business, and economic benefits, ability of fake news to camouflage real news, speed of fake news, unclear definition of fake news, live reporting, uncooperative sources, inexperienced correspondents and interns, social media. The discussion based on findings, literature reviewed and gate keeping theory sought to make sense of the findings in light of previous scholarly works and indicates that the practice of spotting fake news was faced by a myriad of challenges owing to the fact that, there was increased uptake of social media, low or no training of journalists on fake news, typology of fake news, stage managed fake news, live reporting and sources that had ulterior motives.

\section{Recommendations}

From the above discussions, this study recommends that editorial boards in TV stations engage the services of data experts and fake news specialists whether in-house or consultancy. These experts will train both interns and current employees on the typologies, styles, propagation and use of fake new. As Berinsky and Pogue advice experts are instrumental in equipping journalists with skills in managing fake news (Berinsky, 2017 \& Pogue, 2017).

This study also recommends an education approach to curb the challenges in spotting fake news. Training of audiences, sources, reporters and editors on fake news will minimize most of the challenges faced by journalists in managing fake news (Bluemle, 2018, Neely-Sardon \& Tignor, 2018, Pogue, 2017).

Since fake news make use of modern communication technology for propagation and dissemination, this study recommends a technology based approach to spotting of fake news to overcome the challenges discussed above. Scholars like Soe (2018) opine that use of modern technology in communication enables journalists to monitor fake news algorithms while online reverse search approaches helps trace it back for facts (Soe, 2018). There are also facts checking websites that journalists can refer to speed up their verification processes.

Lastly, this study recommends an inoculation approach to curb the challenges faced by journalists in spotting fake news. In this approach, media houses expose their audiences to refuted forms of certain news beforehand making audiences more critical and cynical in evaluating certain trending news (Cook, 2017; Lewandowsky \& Ecker, 2017).

\section{References}

Allcott, H., \&Gentzkow, M. (2017). Social media and fake news in the 2016 election. Journal of Economic Perspectives, 31(2), 211-36. 
Bluemle, S. R. (2018). Post-facts: Information literacy and authority after the 2016 Election. portal: Libraries and the Academy, 18(2), 265-282.

Berinsky, A. (2017) "Rumors and Health Care Reform: Experiments in Political Misinformation." The British Journal of Political Science 47(2), 241-262. Retrieved from; $\quad$ https://www.cambridge.org/core/journals/british-journal-of-politicalscience/article/rumors-and-health-care-reform-experiments-in-political misinformation/8B88568CD057242D2D97649300215CF2

Bermúdez, J. P. (2018). The Post-Truth temperament: What makes belief stray from evidence? And what can bring them back together? In C. G. Prado (Ed.), America's Post-Truth Phenomenon: When Feelings and Opinions Trump Facts and Evidence (pp. 87-109). Santa Barbara CA: Praeger.

Brooke, B. (2017). Fact-Checking Won't Save Us From Fake News https://online225.psych.wisc.edu/wp-content/uploads/225-Master/225UnitPages/Unit-02/Borel_FiveThirtyEight_2017.pdf.

Cooke, N. A. (2017). Post-truth, truthiness, and alternative facts: Information behavior and critical information consumption for a new age. The Library Quarterly, 87(3), 211-221.

Cook J., Lewandowsky, S. \&Ecker, U. K. (2017). Neutralizing misinformation through inoculation: Exposing misleading argumentation techniques reduces their influence. PloS one, 12(5), e0175799.

Creswell, W.J. (2007). Qualitative inquiry and research design: Choosing among five approaches. Professional practice in sport psychology: A review (pp.207-337).

Daniels, G. (2017). How fake news works as political machinery to tarnish the integrity of journalists.https://mg.co.za/article/2017-02-15-fake-news-and journalismschadenfreude-and-you [Accessed 1 September, 2019].

Dentith, M. R. X. (2017). The problem of fake news. Public Reason, 8(1-2), 65-79.

Fairfield, P. (2018). Lords of mendacity. In C. G. Prado (Ed.), America's Post-Truth Phenomenon: When Feelings and Opinions Trump Facts and Evidence (pp. 153-164). Santa Barbara CA: Praeger.

Fallis, D. (2004). On verifying the accuracy of information: Philosophical perspectives. Library Trends, 52(3), 463-487.

Gelfert, A. (2018). Fake news: A definition. Informal Logic, 38(1), 84-117.

Goldman, A. I. (2001). Experts: Which ones should you trust? Philosophy and Phenomenological Research, 63(1), 85-110.

Garcia, A. \& Lear, J. (2016, November 2). "5 stunning fake news stories that reached millions by Ahiza Garcia and Justin Lear." https://money.cnn.com/2016/11/02/media/fake-news-stories/index.html

Harsin, J. (2015). Regimes of posttruth, postpolitics, and attention economies. Communication, Culture \& Critique, 8(2), 327-333. 
Himma-Kadakas, M. (2017). "Alternative facts and fake news entering journalistic content production cycle". Cosmopolitan Civil Societies: An Interdisciplinary Journal. 9 (2): 25-41. http"//doi:10.5130/ccs.v9i2.5469.

Housh, A. (2018). Fake News, Political Narrative, \& Social Media: A Structuration Approach. Thesis. SIT graduate Institute, Vermont, USA. Capstone Collection. 3087.

Jamieson, K. H. (2018). Cyberwar: How Russian hackers and trolls helped elect a President. Oxford University Press.

Jwan, J. O. \& Ong'ondo, C. O. (2011). Qualitative Research. An introduction to principles and Techniques. Moi University press, Eldoret.

Khaldarova, I., \&Pantti, M. (2016). Fake news: The narrative battle over the Ukrainian conflict. Journalism Practice, 10(7), 891-901.

Lokot, T., \& Diakopoulos, N. (2016). News Bots: Automating News and Information Dissemination on Twitter. Digital Journalism, 4(6), 682-699. https://doi.org/10.1080/21670811.2015.1081822

Lubanga, D. (2017 February, 14). Moi University Chancellor Dismisses Closure Notice As Fake. Daily Nation.Available https://www.nation.co.ke/news/Notice-on-varsityclosure-is-fake/1056-3812210-qhax5t/index.html

Muthoni, K. (2019). Court awards Jimmy Wanjigi Sh8 million for fake obituary. The Stadard Digital News, May 3, 2019.https://www.standardmedia.co.ke/article/2001323745/wanjigi-wife-getsh8m-for-obituary . Accessed September 4, 2019.

Mutambo, A. (2018, March 15). Government condemns fake news on Moi's health. Daily Nation, p.2. https://www.nation.co.ke/news/Government-condemns-DanielMoi-health-rumour/1056 4341632-dg19oo/index.html

Neely-Sardon, A., \& Tignor, M. (2018). Focus on the facts: A news and information literacy instructional program. The Reference Librarian, 59(3), 108-121.

Obuya, J. \& Ong'ondo, C. (2019). "Caught between a Rock and a Hard Place": How Kenyan Journalists are coping with Pressure for Media Accountability. Journal African Journalism Studies 2(3) pp.1-15.

Pogue, D. (2017). How to stamp out fake news. Scientific American 316 (2), 24-24.

Rochlin, N. (2017). Fake news: belief in post-truth. Library Hi Tech, 35(3), 386-392.

Rubin, H., \& Rubin, I.S. (2005). Qualitative Interviewing: The Art of Hearing Data ( $\left.2^{\text {nd }} e d.\right)$. London: Sage Publications.

Shoemaker, P., \&Vos, T. (2009). Gatekeeping Theory. New York: Routledge.

Silverman, C. (2016). This analysis shows how fake election news stories outperformed real news on Facebook. Retrieved from: https://www.buzzfeed.com/craigsilverman/viralfake-election-news-outperformed-real-news-onfacebook?utm_term=.bhxAQE0e5y\#.iiry21kXv3. 
Silverman, C., \& Singer-Vine, J. (2016). Most Americans who see fake news believe it, new survey says. Retrieved from: https://www.buzzfeed.com/craigsilverman/fakenews-survey.

Soe, S.O. (2018). Algorithmic detection of misinformation and disinformation: Gricean perspectives. Journal of Documentation 74(2), 309-332. https://doi.org/10.1108/JD-05$\underline{2017-0075}$

Steinberg, L. (2017, July 26). Infographic: Beyond Fake News - 10 Types of Misleading News. Retrieved January 4, 2020, from

https://eavi.eu/beyond-fake-news-10-types-misleading-info/

Tandoc, Jr, E. C., Lim, Z. W., \& Ling, R. (2018). Defining "fake news:" A typology of scholarly definitions. Digital Journalism, 6(2), 137-153.

Vamanu, L. (2019), Fake News and Propaganda: A Critical Discourse Research Perspective. Open Information Science, 3:197-208.

Wahutu, J. (2019). Fake news and "Journalistic rules of the game". African Journalism Studies 39(4), 1.

Workman, D. (2017, June 7). Fake-news-stories-that-rocked-africa. http://www.itnewsafrica.com/2017/06/7 